\title{
Research on the Reform of College English Teaching Mode Under the Background of MOOCs
}

\author{
Huifen Lu \\ Jiangxi Vocational College of Industry \& Engineering \\ luhf668@126.com
}

Keywords: MOOCs, College English, Influence, Teaching Strategies

\begin{abstract}
Progress with the development of modern education in our country, for class as a kind of popular online course in recent years education mode, and is taught by video, after-school practice tests, the network interaction and study aspects of interwoven network teaching process, it has greatly changed the traditional mode of teaching, is the result of modern science and technology progress and education development. From the perspective of college English teaching, this paper probes into the influence of MOOCs on college English teaching from the perspectives of significance and challenge, and conducts an in-depth study on the problems of college English teaching strategies in the context of MOOCs.

Longed for class is based on the premise of the development of modern network technology, mu class attached to the network, the source of the participants more widely, for a course of learning achieved a wide range of cultural diversity and participation, to meet the needs of different levels need to learn, we can at any time, anywhere, choose to study courses, greatly facilitate the learners. Although MOOCs does not change the guiding ideology of higher education in essence, this form has a huge impact on the teaching and management of higher education.
\end{abstract}

\section{The Connotation and Characteristics of Mooc}

The connotation of MOOCs. MOOCs originated in the United States. In 2008, the concept of MOOCs was proposed, and in 2011, MOOCs attracted wide attention from the world education circle. MOOCs are massive open online classes that are a learning process for students.For teachers, MOOCs is a display of self-professionalism and a challenge. The teacher's classroom is no longer pure speaking, but many links such as teaching, interaction, experience and detection can be realized on the Internet.Different from the recording of video in open class, mooc is different in that students need to complete the online homework assigned by teachers in addition to watching the recorded teaching video. Students can discuss problems with teachers and finally get the university's recognition certificate.

\section{Characteristics of Mooc}

(1) Openness. In the process of learning mooc, students will not be subject to relevant restrictions such as location.Although there are relevant differences between students and teachers, such as understanding of cultural knowledge and economy, as long as students like, are willing and have time, they can learn in the classroom on the Internet and enjoy high-quality classes.The space of mooc is not only flexible, but also its evaluation system of classroom teaching is objective and automatic, which can obtain scientific test results when teaching in class.At the same time, when students ask questions, they usually get the answers in a few minutes.

(2) Scale. In the course of mooc teaching, the number of students will not be affected or 
limited.In the traditional classroom, when some excellent teachers are teaching in class, most students cannot grab seats because of the limitation of teacher space, and they miss the opportunity to attend lectures.As for mooc teaching, thousands of people can participate in it, which ensures students' learning.

(3) Autonomy. In the classroom choice, MOOCs appears more flexible.Students can choose courses that suit their learning ability and time according to their own situation and arrange their study time independently.For the teaching of video, students can pause and play back at will, and the learning content can be explored repeatedly, which largely meets the learning willingness of students.

\section{The Influence of MOOCs on College English Teaching}

\subsection{The positive significance of mooc in college English teaching}

One is the systematization of mooc knowledge structure, which is conducive to improving the English learning quality of college students.Longed for in college English teaching, the application must be built according to strict scientific system, from the basic to the formation of an English article, grammar is basic to the process of ascension and the curriculum for college English class often use unit classified methods according to the text content, facilitate students to learn and master, greatly improving the efficiency and quality of college students to learn English.Second, MOOCs personalized learning environment is conducive to improve the self-learning ability of college students.In the context of mooc, college English teaching content mostly appears in the form of video, courseware, etc., and its biggest feature is that it can be copied and repeated indefinitely. Therefore, college students can learn according to your own schedule, courses related to not only can log in our web site for autonomous learning, but also can be selectively under the guidance of the teacher read and search all kinds of English materials, can even his English articles on the web, please the teacher give guidance or review with others.It can be seen that the college English teaching in the mooc environment provides students with a very personalized learning environment and effectively exercises their self-learning ability, which is of great benefit to the future development of students.

\subsection{Challenges brought by MOOCs to college English teaching.}

The application of MOOCs in college English teaching also poses new challenges to English teaching.As we all know, English is a language subject, and the study of college English is to improve the English communication ability of college students. In addition, mooc teaching mode, to some extent, seems to reduce the actual English communication between teachers and students, and even become a real "dumb English".In addition, the teaching method of mooc lacks certain binding force, and its learning process depends on the arrangement of students themselves. However, despite participation, homework and tests, the degree of completion of courses and mastery of knowledge of students is yet to be tested.

\section{Analysis of college English teaching strategies under the background of mooc}

\subsection{Choose Teaching Content Reasonably and Make Mooc Materials Scientifically}

In the context of mooc, college English teaching cannot be separated from the preparation of mooc materials, and the quality of courseware making directly or indirectly affects the quality of students' English learning, which poses a new challenge to college English teachers. 
For this reason, in the initial stage of mooc teaching method, English teachers must first choose those English teaching video which is moderate in difficulty as mooc materials, and add more detailed teacher's explanation, so as to reduce the strangeness of students to this new teaching method. In order to arouse students' interest in learning English in mooc, they can also add their interest in celebrity stories, relevant proverbs, interesting pictures and video to the courseware, so as to attract more students to finish the course as soon as possible. Of course, in the immature stage of the development of mooc teaching mode, English teachers should also answer students' problems in the course of mooc learning to ensure the effectiveness of mooc teaching.

\subsection{Innovate teaching methods in combination with college teaching practice}

As a new learning method in recent years, the application of MOOCs in the practical teaching of college English should follow the principle of gradual progress, so as to avoid some college students' difficulty in adapting to the drastic reform.Therefore, different colleges and universities can actively innovate teaching methods according to the actual situation of students and campus resources.

Generally speaking, in the current college English teaching, fully use of class teaching method is obviously not practical, therefore, college English teachers can speak traditional face-to-face teaching method combined with mu class teaching, on the basis of retain the original oral teaching and learning in class to add some video resources for class, let the students discuss each other, learn English knowledge in different areas use mode and use skills, in the active study atmosphere adds more knowledge of English.

4.3 Effectively embed part of the test to ensure the learning effect of MOOCs.

Many college English teachers say that teaching English in the context of MOOCs is difficult to verify students' actual level, and it is not easy to supervise students to finish the course.

In order to change this situation, college English teachers can in class for information embedded in the test for the contents of the foregoing, embed a every once in a while, only accurate pass a test in order to proceed the following course of study, both to ensure that students complete courses, can also be effective test the students of class effect, causes the student to always maintain a high level of attention.

\section{Conclusion}

To sum up, with the development of "MOOCs", the possibility of opening up the core resources of universities to the whole society will be gradually revealed, which makes the cultivation of English talents and social service in universities more and more interactive.As a new teaching mode, mooc is a revolution to the traditional teaching mode. As college English teachers, we should view this new teaching model with an open mind, constantly improve ourselves, actively explore the specific application of MOOCs in college English teaching, and constantly promote education to achieve a qualitative leap. 


\section{References}

[1] Chen Yunru. Coping strategies for college English teaching reform under the impact of MOOCs [J]. Contemporary youth monthly, 2015 (03).

[2] Zhang Junni. Problems and countermeasures in college English teaching in mucsu era [J]. New western (theoretical version), 2015 (06).

[3] Zhang Chunli. An analysis of college English teaching strategies in the context of mooc [J]. Education study of new curriculum: study of foreign language teaching methods, 2014 (07). 